\title{
THE STRUCTURE OF MOTOR FITNESS OF YOUNG FOOTBALLERS IN A THREE-YEAR SPORTS PERIOD
}

\author{
Edward Mleczko ${ }^{1,3}$, Elżbieta Cieśla ${ }^{3}$, Grażyna Nowak-Starz ${ }^{3}$, Jan Jaščaninas ${ }^{2,4}$ \\ Academy of Physical Education ${ }^{1}$, Cracow, Poland, Lithuanian Academy of Physical Education ${ }^{2}$, Kaunas, \\ Lithuania, Saint Cross University ${ }^{3}$, Kielce, Poland, Politechnika Opole ${ }^{4}$, Opole, Poland
}

Edward Mleczko. Professor, Dr. Habil. at Academy of Physical Education in Cracow and Saint Cross University in Kielce, Poland. The field of scientific research — kinesiology, sport sciences: adaptation of sportsmen's organism to loads during training sessions and competitions.

\begin{abstract}
In the continuous research, conducted in the sports school in Tarnów (Poland) with a football profile, the authors attempted to find out whether the changes of hidden predispositions and motor abilities appear during the training process which constitute the foundation for the development of technical and tactic fitness against the background of the similar research results carried out in the comparative groups of non-training individuals. In the research the measurements of the basic somatic traits, anthropometric indexes, $\mathrm{VO}_{2 \text { max }} \times \mathrm{kg}^{-1}$ and motor skills were taken into consideration. The observations were made every six months for three years. The comparative group consisted of the peers with attending randomly chosen schools (comparative group). The conducted factor analysis revealed the fact that there are minor quantitative differences of the motor structure between training and non-training groups during a three-year observation period. In both the sportsmen's and less physically active boys' groups the number of separated factors did not increase as well as the set of variables taken into account. It can be concluded then, that the applied way of sports selection as well as the process of their adaptation to a specific training ballast might have been the causative factor of the structure efficiency specification among children from sports schools. In this connection, they cannot deny the thesis that a talented sports master can be recognized already as a child. Still, the ways of such a selection seem controversial.
\end{abstract}

Keywords: the structure of motor fitness of young footballers, continuous research, factor analysis.

\section{INTRODUCTION}

$\mathrm{O}$ $\mathrm{n}$ the grounds of the number of works devoted to recruitment and selection of children to doing record-seeking sports it can be seen that the mentioned problem has already been solved. But the practice does not confirm it. In many cases the cognitive results of scientific research are inapplicable in sports training. According to the American physiologist D. L. Costill (1976) a training is an art. There are many objective reasons for that statement.
Their origin can be looked for in a still unknown nature of a man taking part in sports competitions, as well as in methodological errors and technological insufficiency influencing the quality and confidence of the empiric research conclusions.

In the following report we would like to pay attention to a debatable nature of the theoretical and practical assumptions on which, maybe not only in Poland, some theoretical assumptions of 
a recruitment and selection system to practising sports have been based.

Not looking into details, the model of a sports training with children in sports clubs (Ważny, 1981) as well as in classes with extra hours of physical training (Raczek, 1981) is based on the assumption that sports development should take place by stages, as a result of the stimulation of natural somatic, functional and motorial development of the process of formation, on such a base, specific tactic and technical skills. From the review of literature it appears that despite long-term research on a training of biological characteristics such a problem still remains open. It is shown, among others, by the research on development stability of the basic structural and functional characteristics done in some sports schools in Cracow (Szopa et al., 1996). On the grounds of the research it is believed that there are objective reasons for low efficiency of the undertaken pedagogical effects aiming at bringing out changes of an adjustment nature in the level of development of biological characteristics with children qualified to sports training. Leaving out the fact that the applied selection tests favour the qualification of not very ecosensitive homozygotes, aspiration for the selection of the individuals with the highest level of somatic, functional and motorial development makes it impossible to achieve after-training alterations among the characteristics whose development reached its maximum. After all, the frame of a biological adaptation cannot be exceeded in a natural way. Because of that, the recommended, in many cases, increase in the intensity of training charge with children may be questionable.

In the light of the latest Cracow research also some regularities of the formation during the development of individual motorial potential turn out to be controversial. So far, on the grounds of Russian researchers' opinion, the assumption that the younger the children, the more comprehensively the motor potential manifests itself, traditionally called 'motor abilities' (Filippowič, Turewskij, 1977). The specification of particular motor skills appears in a natural way only during the ontogenetic development.

J. Januszewski and E. Mleczko's work (2003) shows that the same Russian method, which constituted the basis for drawing such a conclusion, used for the analysis of the materials coming from the research of optionally chosen biological characteristics among non-training girls and boys from Małopolska region, does not confirm the biological regularities taken so far for granted. Factor analysis does not show the increase in the number of the separated factors as the years go by or because of an increase in age. Besides, the percentage of the statistically important crucial differences in a correlation matrix among both girls and boys has increased and it was supposed to decrease. It seems that such a result of the search for biological regularities with the applied multivariable statistical models should lead to verification of the so-far views on the methods of stimulation of motorial ability development during the ontogenetic development. It should also reinforce the suggestion that a potential sports champion can and should be recognized at the teenage. As the authors of the mentioned above works underline (Januszewski, Mleczko, 2003) there exists: “< ..> one very important factor, which may shake the reliability of the results acquired by them and others they were referred to".

And so, in accordance with the methodology of auxological works, the problem of development dynamics should be looked into on the basis of the materials coming from longitudinal observation.

Therefore, in the following study the mentioned problem was looked into on the grounds of the results coming from longitudinal research on pupils of sports classes of football section and pupils of the same age attending other extra sports and recreation activities apart from physical education and some spontaneous participation in various forms of motor activity.

1) Will a motor potential of students in sports classes qualified to sports training only on the grounds of the results of trainers' observation on predisposition to playing football differ from that of students of the same age who have not practised in any arranged way of physical activities?

2) May practising sports by children result in a change, in a specific way, of taxonomy of 21 variables (somatic and functional characteristics as well as motor abilities) taken into consideration in factor analysis?

3) Will a phenomenon of gradual separating of basic motor abilities out of general motor potential come out during the ontogeny of nontraining children? 


\section{MATERIAL AND METHODS}

The subject of the longitudinal observation was a group of 30 boys qualified to sports training in the fourth grade, as mentioned before, on the grounds of the trainers' observation of football abilities among the participants of 10 -year-old team competitions. They were organized each year by the sports club "Unia Tarnów” — Poland. Apart from high marks given by trainers, to be qualified to a sports club they needed their parents' consent and doctor's opinion on training in a sports school. No other selection criterion was applied. The boys of a sports group apart from compulsory physical training 2 hours a week attended special classes for 5 hours a week. They aimed at shaping motor efficiency and basic technical abilities of the future footballers. In the next three years of observation the intensity of ballast was changed while the proportion of the objective structure of the training was quite stable.

A comparative group consisted of 90 nontraining men of the same age chosen randomly from pupils of schools in Tarnów (Poland), who declared in the questionnaires that they did not practise any motor activities except for the compulsory physical training. Such interests were corrected yearly which resulted in the decrease in the number of pupils in the group by 12 in the last research. Only one of the qualified pupils stopped education in a sports class (Table 1 ).

The observations were done six times in the following terms: $15.09-30.09$ and $15.04-$ 30.04. It is worth pointing out that the interval between spring and autumn term of the research was shorter, parted by the two-month-break, which the pupils of sports schools went on a 14-day-training camp. The way of sending vacation time by the members was not monitored.

The scope, tools and techniques of the re- search. The same measurements of basic somatic, functional characteristics and motor abilities were taken in both sports and control group. The measurements of body height and mass, thickness of an adipose tissue (of scapula and shoulder), as well as arm, forearm, thigh and shank measurements were taken in accordance with the methods commonly used in somatometry.

Oxygen efficiency was defined with indirect measurement method $\mathrm{VO}_{2 \text { max }} \times \mathrm{kg}^{-1}$ using modified Margarii \& Co. test (Januszewski, 1981).

For the measurement of motor efficiency applied:

- Selected trials of Eurofit test (European Test of Physical Fitness, 1993):

- static strength, explosive strength, arms' strength, abdominal strength, shuttle run, frequency of movement, balance.

- Instrumental measurement of psychomotoric ability using:

- cross apparatus AKN-102 with a forced series of light stimulus emission,

- Piórkowski’s apparatus with indicated frequency of light stimulus emission 107 / min.

Methods of working out the results of the research:

- The percentage of fat content at the examined was counted out of the measurements of adipose tissue and its fat mass (FM), lean body mass (LBM) were calculated in relation to body mass.

- The ponderal index (WSM) was calculated with the quotient of the height and cubic rot.

- Basic statistic characteristics: arithmetic mean (), standard variation (s) and variability index (v) were calculated for all the investigated characteristics, indexes and measurements of motoric abilities. The size of the fattening of the

\begin{tabular}{|c|c|c|}
\hline Research & Training group (n) & Control group (n) \\
\hline I & 30 & 90 \\
\hline II & 30 & 90 \\
\hline III & 30 & 90 \\
\hline IV & 30 & 90 \\
\hline V & 30 & 90 \\
\hline VI & 29 & 78 \\
\hline
\end{tabular}

Table 1 . The number of $11-13$ yearold-boys in the particular researches 
normal cure (Gausa) was estimated using variability index (v) and Kołmogorova—Smirnova’s test.

- Correlation matrixes were calculated on the grounds of rough results and normalized percentage numbers as well as the size of crucial relations between the examined parameters. In order to compare the significance of differences on the grounds of the test results for the twostructure index (Greń, 1976).

- Besides, the correlation matrixes were used for factor analysis taking into consideration rough and normalized results. The variant used was based on the method of Hotteling's main components, modified by Tucker and completed by the Varimax rotation suggested by Kaiser (Czyż, 1971), taking for granted the independence of the factors. It allowed to learn their structure within one series of variables.

\section{RESULTS OF THE RESEARCH}

Looking for the answer to the first research question the attention should be paid to the results of the two stages of the factor analysis. In the first, basing on the correlation matrix, the strength of relations between the particular parameters was looked into. The next focus was the final effect of the applied statistic analysis, which aimed at selecting a definite number of factors. Finally, the interest was taken in the identification of the structure of the selected factors, that is, theoretical, independent of each other orthogenic variables, with the help of which the variance of empiric variables was explained and reduced.

Evaluating the differences of motoric potential between the sports group and the comparative one, on the grounds of the results of the correlation matrix analysis of the investigated parameters in the first stage, it must be stated that in the first there was a smaller number of statistically important connections between variables in the group of boys selected to playing record-seeking football (Table 2). The importance of the statistic differences between mentioned above relations confirm the effects of the significance test of structure factors.

They pointed to independence of the investigated elements of motoric efficiency and somatic structure of motorically active boys. Such a situation was confirmed by the next stages of the applied statistic analysis. Its results allow to select a larger number of factors in the sports group than in the control group, or describing in a mathematical way: 'homogenic subpopulation among the objects coming from a heterogenic population' (Marek and Noworol, 1983). In this way, independent of each other orthogenetic, theoretical variables were identified, with the help of which the variance of 21 initial (empiric) variables was explained and reduced. And the substance of new theoretical variables was defined as a result of the analysis of so called 'factor loads' that is the degree of their correlation with empiric variables. On this base it can be stated that the boys qualified to sports classes on the grounds of experts' opinion on their skills and usefulness for playing football differ in the number of hypothetical variables called factors from those who do not practise any sports except for compulsory classes. The applied statistic analysis showed in the mentioned above group a bigger possibility of the reduction of the multi characteristic initial set of variables. Besides, in the sports group there can be noticed not only a bigger number of concentration of the investigated parameters, but above all, more 'crumbled' structure of motoric potential. In the control group it had more general structure (Tables 3, 4).

On account of this, it can be believed that there must have been a relation between the recognized by the trainers' abilities and motor skills of candidates for sports classes and the specificity

\begin{tabular}{|c|c|c|c|c|c|c|c|c|}
\hline \multicolumn{2}{|c|}{ Studies } & 1 & 2 & 3 & 4 & 5 & 6 & \multirow{7}{*}{$\begin{array}{l}\text { Table } 2 \text {. The number of fac- } \\
\text { tors selected in the succe- } \\
\text { eding constant researches } \\
\text { of three groups and the } \\
\text { range of general variability } \\
\text { (ZZW) and \% of the varia- } \\
\text { tion of common variability } \\
\text { and factor I }\end{array}$} \\
\hline \multirow[t]{2}{*}{ Numbers of factors } & Training group & 6 & 6 & 6 & 6 & 6 & 6 & \\
\hline & $\begin{array}{l}\text { Comparative } \\
\text { group }\end{array}$ & 4 & 4 & 5 & 4 & 5 & 4 & \\
\hline \multirow[t]{2}{*}{$\mathrm{ZZW}$} & Training group & 77.10 & 77.26 & 76.21 & 77.32 & 77.03 & 84.09 & \\
\hline & $\begin{array}{l}\text { Comparative } \\
\text { group }\end{array}$ & 66.10 & 66.46 & 70.31 & 66.89 & 74.78 & 72.36 & \\
\hline \multirow{2}{*}{$\begin{array}{c}\% \text { of common } \\
\text { variance of factor I }\end{array}$} & Training group & 34.56 & 35.19 & 34.69 & 35.03 & 34.75 & 35.04 & \\
\hline & $\begin{array}{l}\text { Comparative } \\
\text { group }\end{array}$ & 34.09 & 34.27 & 33.24 & 33.87 & 32.57 & 32.76 & \\
\hline
\end{tabular}


of their motoric efficiency. And because it was differentiated it could be supposed that at the same time it could be better adapted to the needs of a future football champion.

Although for trainers such a conclusion may not be revealing, in the context of the discussed problem and the results of Russian sports theoretists' research, the results of the individual research give evidence for refutation of the opinions on training procedure based on them. They rather suggest that the applied selection procedure was effective. On the grounds of their own experience trainers can, with high accuracy know a teenaged child for a future gifted footballer and they do not have to conduct too expensive and labourconsuming laboratory tests at a stage of an initial selection.

The results of the further analysis of the materials collected in longitudinal individual research may convince, seemingly, so far-reaching hypothesis. Efforts have been made, among others, to answer the following question:
'Will the changes in the structure of motoric potential during the ontogeny between the age of $11-13$ be of similar scope and direction with both children of low motor activity and those, who trained a sport for three years?'

At the beginning of the presentation of the results of individual research it must be stated that they did not give foundations for confirming W. I. Filippowič and I. M. Turewskij's (1977) suggestions referring to a tendency to a decrease in statistically important relations between the studied parameters together with age and the same the possibility of separation during the children's ontogeny a larger number of factors.

The achieved results were, then, similar to those of J. Januszewski and E. Mleczko (2003) obtained in the analysis of materials coming from population research.

Tables 5-10 presents the results of the factor analysis in the succeeding six researches done during the period of 3 years.

They give foundation for the statement that in

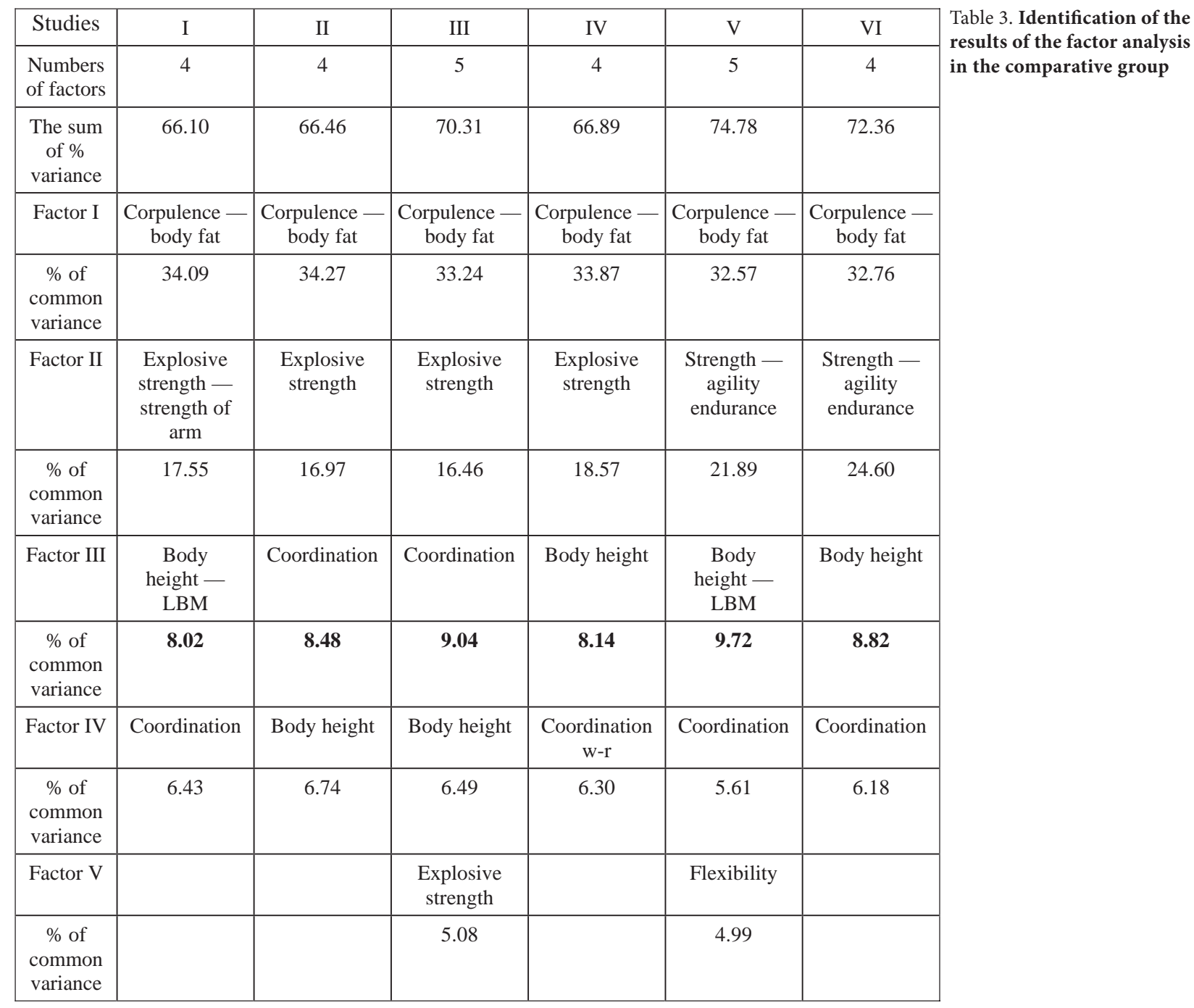


Table 4. Identification of the results of the factor analysis in the training group

\begin{tabular}{|c|c|c|c|c|c|c|}
\hline Studies & I & II & III & IV & V & VI \\
\hline $\begin{array}{l}\text { Number of } \\
\text { factors }\end{array}$ & 6 & 6 & 6 & 6 & 6 & 6 \\
\hline $\begin{array}{l}\text { Sum of \% } \\
\text { common } \\
\text { variability }\end{array}$ & 77.70 & 77.26 & 76.21 & 77.32 & 77.03 & 84.09 \\
\hline Factor I & $\begin{array}{c}\text { Corpulence - } \\
\text { body fat }\end{array}$ & $\begin{array}{c}\text { Corpulence - } \\
\text { body fat }\end{array}$ & $\begin{array}{c}\text { Corpulence - } \\
\text { body fat }\end{array}$ & $\begin{array}{c}\text { Corpulence - } \\
\text { body fat }\end{array}$ & $\begin{array}{c}\text { Corpulence - }- \\
\text { body fat }\end{array}$ & $\begin{array}{c}\text { Corpulence - } \\
\text { body fat }\end{array}$ \\
\hline $\begin{array}{c}\% \text { of } \\
\text { common } \\
\text { variance }\end{array}$ & 34.56 & 35.19 & 34.69 & 35.03 & 34.75 & 35.04 \\
\hline Factor II & $\begin{array}{c}\text { Agility } \\
\text { Abdominal } \\
\text { mm. strength }\end{array}$ & $\begin{array}{l}\text { Balance } \\
\text { Agility }\end{array}$ & $\begin{array}{c}\text { Agility } \\
\text { Abdominal } \\
\text { mm. strength } \\
\text { endurance }\end{array}$ & $\begin{array}{c}\text { Body height } \\
\text { static strength }\end{array}$ & $\begin{array}{l}\text { Height - } \\
\text { strength }\end{array}$ & $\begin{array}{l}\text { Height, LBM, } \\
\text { static strength }\end{array}$ \\
\hline $\begin{array}{l}\text { \% of } \\
\text { common } \\
\text { variance }\end{array}$ & 15.81 & 14.32 & 11.49 & 13.53 & 15.61 & 16.27 \\
\hline Factor III & $\begin{array}{l}\text { Height - } \\
\text { LBM }\end{array}$ & $\begin{array}{c}\text { Body height } \\
\text { static strength }\end{array}$ & Height & $\begin{array}{c}\text { Agility } \\
\text { Abdominal } \\
\text { mm. strength }\end{array}$ & Balance & $\begin{array}{l}\text { Agility } \\
\text { strength of } \\
\text { arms }\end{array}$ \\
\hline $\begin{array}{l}\text { \% of } \\
\text { common } \\
\text { variance }\end{array}$ & 9.96 & 9.50 & 9.65 & 9.20 & 11.15 & 11.98 \\
\hline Factor IV & $\begin{array}{l}\text { Balance, } \\
\text { coordination }\end{array}$ & Flexibility & $\begin{array}{c}\text { Effort } \\
\text { Efficiency }\end{array}$ & $\begin{array}{c}\text { Effort } \\
\text { Efficiency }\end{array}$ & $\begin{array}{c}\text { Effort } \\
\text { Efficiency }\end{array}$ & $\begin{array}{c}\text { Space } \\
\text { orientation }\end{array}$ \\
\hline $\begin{array}{l}\text { \% of } \\
\text { common } \\
\text { variance }\end{array}$ & 7.01 & 7.45 & 8.00 & 8.00 & 9.73 & 10.48 \\
\hline Factor V & Flexibility & Coordination & $\begin{array}{c}\text { Balance, } \\
\text { coordination }\end{array}$ & Flexibility & $\begin{array}{c}\text { Explosive } \\
\text { strength, space } \\
\text { orientation }\end{array}$ & $\begin{array}{l}\text { Hand } \\
\text { movement } \\
\text { frequency }\end{array}$ \\
\hline $\begin{array}{l}\text { \% of } \\
\text { common } \\
\text { variance }\end{array}$ & 5.30 & 5.86 & 6.71 & 6.46 & 7.06 & 5.47 \\
\hline Factor VI & $\begin{array}{c}\text { Effort } \\
\text { Efficiency }\end{array}$ & $\begin{array}{l}\text { Hand } \\
\text { movement } \\
\text { frequency }\end{array}$ & Flexibility & $\begin{array}{c}\text { Frequency of } \\
\text { movement }\end{array}$ & $\begin{array}{l}\text { Agility } \\
\text { Endurance }\end{array}$ & $\begin{array}{l}\text { Explosive } \\
\text { strength }\end{array}$ \\
\hline $\begin{array}{l}\text { \% of } \\
\text { common } \\
\text { variance }\end{array}$ & 5.07 & 4.95 & $5, .67$ & 5.09 & 5.36 & 4.86 \\
\hline
\end{tabular}

the succeeding researches the same in number of six factors was identified in the group of training boys. A similar situation was observed in the group of non-training boys. At the time a tolerable stability of a smaller number of separated concentrations was shown. It increased only twice from four to five. It must be pointed out that such an increase was noticed after a holiday break and resulted in revealing connections having weak participation in explaining common variance (5.05 and $4.9 \%)$.

It seems difficult to connect such a case with the phenomenon of differentiation of the motoric potential under the influence of biological development of the examined. Ignoring the fortuity, possible, after all, to occur in a statistic study, it should be supposed that it was rather an effect of the increased motor activity, which may be observed during the holiday break among less active children at school time.

It seems that, to a high degree, the earlier presented hypothesis may be confirmed by the results of the variability analysis in the substance of the factors or, in other words, the results of the analysis of the 'load' value of the characteristics and motor abilities that formed them. As it is well known, a factor analysis assumes that the selected concentrations are not variables which can be observed indirectly. Besides, the rules of interpretation do not lead to their substantiation in a satisfactorily precise way. Generally, in the description of the factor, only such initial variables are taken into account for which the contribution (load) of the factor is the largest. 


\begin{tabular}{|c|c|c|c|c|c|c|c|c|c|c|}
\hline \multirow[b]{2}{*}{ Factors } & \multicolumn{4}{|c|}{ Comparative group } & \multicolumn{6}{|c|}{ Training group } \\
\hline & I & II & III & IV & I & II & III & IV & V & VI \\
\hline Body height & & & 0.90 & & & & 0.93 & & & \\
\hline Body mass & 0.88 & & & & 0.80 & & 0.56 & & & \\
\hline WSM & -0.91 & & & & -0.89 & & & & & \\
\hline FM & 0.90 & & & & 0.91 & & & & & \\
\hline LBM & 0.64 & & 0.68 & & 0.57 & & 0.77 & & & \\
\hline Balance & & & & 0.42 & & & & 0.70 & & \\
\hline Flexibility & & 0.56 & & & & & & & 0.78 & \\
\hline Static strength & & & & & & & 0.68 & & & \\
\hline Explosive strength & & 0.71 & & & & & & & 0.54 & \\
\hline Run speed & & 0.65 & & & & 0.81 & & & 0.62 & \\
\hline Strength of arm & & 0.70 & & & & & & & 0.66 & \\
\hline Abdominal strength & & 0.69 & & & & 0.76 & & & & \\
\hline Endurance & & & & & & & & & 0.62 & \\
\hline $\mathrm{VO}_{2 \max }$ & & & & & & & & & & 0.85 \\
\hline \multicolumn{11}{|l|}{ Movement frequency } \\
\hline Space orientation & & & & 0.78 & & & & 0.59 & & \\
\hline Co-ordination & & & & 0.77 & & & & 0.75 & & \\
\hline Forearm circumference & 0.90 & & & & 0.87 & & & & & \\
\hline Arm circumference & 0.94 & & & & 0.96 & & & & & \\
\hline Shank circumference & 0.83 & & & & 0.82 & & & & & \\
\hline Thigh circumference & 0.93 & & & & 0.91 & & & & & \\
\hline$\%$ common variability & 34.09 & 17.55 & 8.02 & 6.43 & 34.56 & 15.81 & 9.96 & 7.01 & 5.30 & 5.07 \\
\hline
\end{tabular}

\begin{tabular}{|l|c|c|c|c|c|c|c|c|c|c|}
\hline \multirow{2}{*}{ Factors } & \multicolumn{9}{|c|}{ Comparative group } & \multicolumn{7}{c|}{ Training group } \\
\hline & I & II & III & IV & I & II & III & IV & V & VI \\
\hline Body height & & & & 0.91 & & & 0.88 & & & \\
\hline Body mass & 0.88 & & & 0.43 & 0.85 & & & & & \\
\hline WSM & -0.91 & & & & -0.88 & & & & & \\
\hline FM & 0.90 & & & & 0.89 & & & & & \\
\hline LBM & $0 . .65$ & & & 0.66 & 0.68 & & 0.69 & & & \\
\hline Balance & & & 0.51 & & & 0.78 & & & & \\
\hline Flexibility & & 0.60 & & & & & & 0.76 & & \\
\hline Static strength & & & & 0.53 & & & 0.73 & & & \\
\hline Explosive strength & & 0.71 & & & & & 0.57 & & & \\
\hline Run speed & & 0.61 & & & & 0.71 & & & & \\
\hline Strength of arm & & 0.61 & & & & & & 0.69 & & \\
\hline Abdominal strength & & 0.65 & & & & 0.76 & & & & \\
\hline Endurance & & 0.69 & & & & 0.68 & & & & \\
\hline VO ${ }_{2}$ max & & 0.45 & & & & & & & $-0,69$ & \\
\hline Movement frequency & & 0.52 & & & & & & & & 0.83 \\
\hline Space orientation & & & 0.79 & & & & & 0.59 & & \\
\hline Co-ordination & & & 0.77 & & & & & 0.75 & 0.77 & \\
\hline Forearm circumference & 0.91 & & & & 0.86 & & & & & \\
\hline Arm circumference & 0.95 & & & & 0.96 & & & & & \\
\hline Shank circumference & 0.84 & & & & 0.82 & & & & & \\
\hline Thigh circumference & 0.93 & & & & 0.91 & & & & & \\
\hline \% common variability & $\mathbf{3 4 . 2 7}$ & $\mathbf{1 6 . 9 7}$ & $\mathbf{8 . 4 8}$ & $\mathbf{6 . 7 4}$ & $\mathbf{3 5 . 1 9}$ & $\mathbf{1 4 . 3 2}$ & $\mathbf{9 . 5 0}$ & $\mathbf{7 . 4 5}$ & $\mathbf{5 . 8 6}$ & $\mathbf{4 . 9 5}$ \\
\hline
\end{tabular}

Table 5. The results of the factor analysis in the research I
Table 6 . The results of the factor analysis in the research II 
Table 7. The results of the factor analysis in the research III

\begin{tabular}{|c|c|c|c|c|c|c|c|c|c|c|c|}
\hline \multirow[b]{2}{*}{ Factors } & \multicolumn{5}{|c|}{ Comparative group } & \multicolumn{6}{|c|}{ Training group } \\
\hline & I & II & III & IV & $\mathrm{V}$ & I & II & III & IV & $\mathrm{V}$ & VI \\
\hline Body height & & & & 0.82 & & 0.41 & & 0.87 & & & \\
\hline Body mass & 0.91 & & & & & 0.89 & & 0.41 & & & \\
\hline WSM & -0.85 & & & & & -0.81 & & & & & \\
\hline FM & 0.88 & & & & & 0.88 & & & & & \\
\hline LBM & 0.73 & & & 0.55 & & 0.76 & & 0.59 & & & \\
\hline Balance & & & 0.57 & & & & & & & 0.77 & \\
\hline Flexibility & & 0.54 & & & & & & & & & 0.84 \\
\hline Static strength & & & & & 0.73 & & & 0.51 & 0.60 & & \\
\hline $\begin{array}{l}\text { Explosive } \\
\text { strength }\end{array}$ & & 0.70 & & & & & & & & & 0.55 \\
\hline Run speed & & 0.67 & & & & & -0.73 & & & & \\
\hline $\begin{array}{l}\text { Strength of } \\
\text { arm }\end{array}$ & & & & & & & & & 0.51 & & \\
\hline $\begin{array}{l}\text { Abdominal } \\
\text { strength }\end{array}$ & & 0.66 & & & & & -0.71 & & & & \\
\hline Endurance & & 0.76 & & & & & -0.76 & & & & \\
\hline $\mathrm{VO}_{2 \max }$ & & & & & 0.53 & & & & 0.78 & & \\
\hline $\begin{array}{l}\text { Movement } \\
\text { frequency }\end{array}$ & & & & & & & & & 0.61 & & \\
\hline $\begin{array}{l}\text { Space } \\
\text { orientation }\end{array}$ & & & 0.79 & & & & & & & 0.59 & \\
\hline Co-ordination & & & 0.80 & & & & & & & 0.73 & \\
\hline $\begin{array}{l}\text { Forearm } \\
\text { circumference }\end{array}$ & 0.92 & & & & & 0.90 & & & & & \\
\hline $\begin{array}{l}\text { Arm } \\
\text { circumference }\end{array}$ & 0.93 & & & & & 0.96 & & & & & \\
\hline $\begin{array}{l}\text { Shank } \\
\text { circumference }\end{array}$ & 0.84 & & & & & 0.88 & & & & & \\
\hline \begin{tabular}{|l|} 
Thigh \\
circumference
\end{tabular} & 0.87 & & & & & 0.76 & & & & & \\
\hline $\begin{array}{l}\% \text { common } \\
\text { variability }\end{array}$ & 33.24 & 16.46 & 9.04 & 6.49 & 5.08 & 34.69 & 11.49 & 9.65 & 8.00 & 6.71 & 5.67 \\
\hline
\end{tabular}

Tables 3-4 present also the results of the applied factor analysis of the individual research, taking into account factor loads, whose value exceeded 0.5 and the results of an individual identification of the meaning of some theoretical variable sets, with the help of which the variance of initial variables was explained and reduced.

The data presented in those tables show that in both groups, in the succeeding six researches, the highest percentage of common variance (32.76$35.19 \%)$ was explained by the factor, which on the grounds of the size of the factor loads, was called corpulence - body fat. It included such characteristics as: body mass, body fat, LBM, ponderal index and forearm, arm, thigh and shank measurements.
In some age-groups, it also included in the control group, the results of strength abilities, measurements of hand strength of the upper limbs and dynamometric measurement of hand grip, and in a sports group, the measurement of endurance abilities and eye-movement coordination. However, it is difficult to connect this phenomenon with any biological regularity. The connection may have just been accidental. In this situation, it may be believed that in both groups, with a set of taken into account somatic characteristics forming the dominant factor, the variances of the initial variables can be explained.

The next factors separated in the individual research are not as simple to identify as the previous one. It may be confirmed by the presented in the 


\begin{tabular}{|c|c|c|c|c|c|c|c|c|c|c|}
\hline \multirow[b]{2}{*}{ Factors } & \multicolumn{4}{|c|}{ Comparative group } & \multicolumn{6}{|c|}{ Training group } \\
\hline & I & II & III & IV & I & II & III & IV & V & VI \\
\hline Body height & & & 0.87 & & & 0.88 & & & & \\
\hline Body mass & 0.89 & & & & 0.83 & 0.51 & & & & \\
\hline WSM & -0.87 & & & & -0.86 & & & & & \\
\hline FM & 0.86 & & & & 0.91 & & & & & \\
\hline LBM & 0.69 & & 0.61 & & 0.62 & 0.69 & & & & \\
\hline Balance & & & & & & & & & & -0.53 \\
\hline Flexibility & & 0.52 & & & & & & & 0.86 & \\
\hline Static strength & & & & & & 0.70 & & & & \\
\hline Explosive strength & & 0.75 & & & & 0.54 & & & 0.61 & \\
\hline Run speed & & 0.61 & & & & & 0.70 & & 0.50 & \\
\hline Strength of arm & & 0.63 & & & & & & & & \\
\hline Abdominal strength & & 0.68 & & & & & 0.75 & & & \\
\hline Endurance & & 0.78 & & & -0.61 & & & & & \\
\hline $\mathrm{VO}_{2 \max }$ & & 0.52 & & & & & & -0.88 & & \\
\hline Movement frequency & & 0.56 & & & & & & & & -0.76 \\
\hline Space orientation & & & & 0.58 & & & 0.68 & & & \\
\hline Co-ordination & & & & 0.80 & & & & & & 0.63 \\
\hline Forearm circumference & 0.92 & & & & 0.85 & & & & & \\
\hline Arm circumference & 0.95 & & & & 0.94 & & & & & \\
\hline Shank circumference & 0.85 & & & & 0.88 & & & & & \\
\hline Thigh circumference & 0.93 & & & & 0.90 & & & & & \\
\hline \% common variability & 33.87 & 18.57 & 8.14 & 6.30 & 35.03 & 13.53 & 9.20 & 8.00 & 6.46 & 5.09 \\
\hline
\end{tabular}

Table 8 . The results of the factor analysis in the research IV

chart trail to do such a task. Its results demonstrate that, with the same number of factors separated in the succeeding researches, in a sports group and of their little differentiation in the control group, the value of factor loads and their contribution to the structure of the particular factors is subject to a large differentiation. However, with such variability, some regularity was observed. And so, the number of characteristics, whose factor loads were of high value in the first research changed only to a small degree. In the following stages of the research they mixed together, creating different sets giving meaning to the individual factors. Such a tendency is better observed in the sports group than it the control one.

Apart from that, quite a characteristic phenomenon is the fact that in the non-training group the second high concentration (16-24\% of common variance) at all stages of the research was created by a group of most basic co-ordination abilities and the measurements of efficiency and frequency of movements. It can be believed then, that we have something to do with a sign of revealing in a general way a group of motoric abilities.
As it appears from the above, such regularity cannot then confirm W. I. Filippowič and I. M. Turewskij's (1977) views. They suggested the probability of appearance during an ontogenetic development an occurrence of disintegration of general motoric potential.

To same extent it could be presumed that the mentioned hypothesis may be supported by the results of the analysis of small range measurement of co-ordination abilities taken into account in the individual research. The mentioned before tendency to a strong integration in a separated factor of motor abilities did not occur during the studied period of ontogenesis. This time it would refer to the area of co-ordination abilities. However, it must be pointed out that, in the analysed case, no intensification of the disintegration of general motoric potential was noticed together with the age. In most cases (except for eye-movement co-ordination and space orientation), the measurements of balance and movement frequency - probably in agreement with their 'hidden' nature - went into the sets in which there were speed abilities (movement frequency is the component of speed) 
Table 9. The results of the factor analysis in the rese$\operatorname{arch} \mathrm{V}$

\begin{tabular}{|c|c|c|c|c|c|c|c|c|c|c|c|}
\hline \multirow[b]{2}{*}{ Factors } & \multicolumn{5}{|c|}{ Comparative group } & \multicolumn{6}{|c|}{ Training group } \\
\hline & I & II & III & IV & V & I & II & III & IV & $\mathrm{V}$ & VI \\
\hline Body height & & & 0.92 & & & & 0.88 & & & & \\
\hline Body mass & 0.82 & & 0.54 & & & 0.84 & & & & & \\
\hline WSM & -0.83 & & 0.43 & & & -0.76 & 0.56 & & & & \\
\hline FM & 0.87 & & & & & 0.85 & & & & & \\
\hline LBM & 0.54 & & 0.75 & & & 0.61 & 0.65 & & & & \\
\hline Balance & & & & & 0.58 & & & 0.85 & & & \\
\hline Flexibility & & & & & 0.83 & & & 0.69 & & & \\
\hline Static strength & & & 0.55 & & & & 0.82 & & & & \\
\hline $\begin{array}{l}\text { Explosive } \\
\text { strength }\end{array}$ & & 0.70 & & & & & & & & 0.81 & \\
\hline Run speed & & 0.79 & & & & & & & & & -0.73 \\
\hline Strength of arm & & 0.64 & & & & & & & -0.64 & & \\
\hline $\begin{array}{l}\text { Abdominal } \\
\text { strength }\end{array}$ & & 0.82 & & & & & -0.78 & & & & \\
\hline Endurance & & 0.80 & & & & & & & & & -0.90 \\
\hline $\mathrm{VO}_{2 \max }$ & & 0.55 & & & & & & & -0.82 & & \\
\hline $\begin{array}{l}\text { Movement } \\
\text { frequency }\end{array}$ & & 0.62 & & & & & & & & & \\
\hline Space orientation & & & & 0.87 & & & & & & -0.75 & \\
\hline Co-ordination & & & & 0.70 & & & & & 0.68 & & \\
\hline $\begin{array}{l}\text { Forearm } \\
\text { circumference }\end{array}$ & 0.87 & & & & & 0.84 & & & & & \\
\hline $\begin{array}{l}\text { Arm } \\
\text { circumference }\end{array}$ & 0.93 & & & & & 0.95 & & & & & \\
\hline $\begin{array}{l}\text { Shank } \\
\text { circumference }\end{array}$ & 0.85 & & & & & 0.81 & & & & & \\
\hline $\begin{array}{l}\text { Thigh } \\
\text { circumference }\end{array}$ & 0.91 & & & & & 0.94 & & & & & \\
\hline $\begin{array}{l}\% \text { common } \\
\text { variability }\end{array}$ & 32.57 & 21.89 & 9.72 & 5.61 & 4.99 & 34.75 & 15.61 & 11.15 & 9.73 & 7.06 & 5.36 \\
\hline
\end{tabular}

and strength abilities (the applied balance measurement correlates strongly with the explosive strength of lower limbs). It is hard then, even in this case, to see the confirmation of the Russian scientists' conception.

Another situation appeared in the sports group. Starting from the first research, separated on a larger scale factors - high loads were shown by a smaller number of characteristics or it was possessed only by a single measurement of a specific characteristic or a motoric ability.

The identification of concentration made on their base allows claiming that there appears a tendency to separating elementary components in each of them and classify them among the certain type of the structure of motor potential, or somatic, or functional characteristics. Such a situation suggests an assumption that the boys who were chosen during a selection not only were able to play football but also possessed a range of motoric potential, which was required to reveal some specific skills. The hierarchical structure reflected the attachment of specific motoric abilities and functional characteristics to the factors explaining the definite percentage of the variance of the whole class of variables. Only a slight modification of the structure occurred in a progress of a sports training. It seems, then, that such an occurrence may have been the result of a variety of the applied training ballast as well as the adaptation of the trainees to specific physical efforts.

\section{DISCUSSION}

The results of the individual research give evidence that the applied model of children's selection to playing football in sports classes was effective. Trainers' expert opinion during matches, 


\begin{tabular}{|c|c|c|c|c|c|c|c|c|c|c|c|}
\hline \multirow[b]{2}{*}{ Factors } & \multicolumn{4}{|c|}{ Comparative group } & \multicolumn{6}{|c|}{ Training group } & \multirow{2}{*}{$\begin{array}{l}\text { Table } 10 \text {. The results of the } \\
\text { factor analysis in the rese- } \\
\text { arch VI }\end{array}$} \\
\hline & I & II & III & IV & I & II & III & IV & $\mathrm{V}$ & VI & \\
\hline Body height & & & 0.94 & & & 0.91 & & & & & \\
\hline Body mass & 0.71 & & 0.67 & & 0.85 & 0.50 & & & & & \\
\hline WSM & -0.85 & & & & -0.69 & 0.60 & & & & & \\
\hline FM & 0.86 & & & & 0.83 & & & & & & \\
\hline LBM & 0.41 & & 0.84 & & 0.63 & 0.73 & & & & & \\
\hline Balance & & 0.55 & & & & & & & & & \\
\hline Flexibility & & 0.47 & & & & & & & & & \\
\hline Static strength & & 0.41 & 0.55 & & & 0.81 & & & & & \\
\hline Explosive strength & & 0.72 & & & & & & & & 0.87 & \\
\hline Run speed & & 0.80 & & & & & 0.75 & & & & \\
\hline Strength of arm & & 0.76 & & & & & 0.72 & & & & \\
\hline Abdominal strength & & 0.81 & & & & -0.60 & & & & & \\
\hline Endurance & & 0.77 & & & & & & & & & \\
\hline $\mathrm{VO}_{2 \max }$ & & 0.63 & & & & & & & & & \\
\hline Movement frequency & & 0.67 & & & & & & & 0.90 & & \\
\hline Space orientation & & & & 0.82 & & & & -0.89 & & & \\
\hline Co-ordination & & & & 0.73 & & & & & & & \\
\hline $\begin{array}{l}\text { Forearm } \\
\text { circumference }\end{array}$ & 0.84 & & & & 0.89 & & & & & & \\
\hline Arm circumference & 0.90 & & & & 0.95 & & & & & & \\
\hline Shank circumference & 0.77 & & 0.50 & & 0.80 & & & & & & \\
\hline Thigh circumference & 0.89 & & & & 0.97 & & & & & & \\
\hline $\begin{array}{l}\text { \% common } \\
\text { variability }\end{array}$ & 32.76 & 24.60 & 8.82 & 6.18 & 35.04 & 16.27 & 11.98 & 10.48 & 5.47 & 4.86 & \\
\hline
\end{tabular}

tactic skills and talent of football candidates for sports training were taken into account in the model. It has been noticed that the motorial potential of the selected, under this criterion, individuals was different from that of the same aged men, who limited their participation in various forms of physical culture only to attending compulsory PE classes. The statistic analysis allowed to reveal a higher number of the hidden variables as a result of the reduction of multicharacteristic initial set of a smaller number of hypothetic variables called factors. The results of the individual research did not support W. I. Filipowič and I. M. Turowski's idea (1977) on a selection in a 'natural' way, that is, under the influence of biological development elementary structures of motorial potential. The analysis of results of the longitudinal research on 21 parameters allowed to notice that the process of a specification of motor efficiency in the early period of ontogenesis has its origin in the phenomenon of a convergence of the elements of motor structure to specific requirements towards tech- nical skills of a footballer. Such a phenomenon was already noticed in the first research on pupils qualified to practising football in sports classes. It turned out that, even on the grounds of very simple methods of assessment of motor skills and abilities among children, it was possible to select boys, whose motorial efficiency was characteristic for the needs of a given sports discipline. It leads to a conclusion that the method of selection of children to sports training in the sports school in Tarnów is well worth recommending.

In a progress of a professional sports training the process of adaptation of the motoric potential of the sports class pupils to specific demands of the trained sports was noticed. This phenomenon did not refer to the group of somatic characteristics separated from the main factor 'body fat'. It seems that it points at the importance of somatic conditions of not only physical development. They may be very important element influencing football efficiency and training effects of children from sports schools. 
The analysis of the materials from the longitudinal research on pupils of a small motor activity shows a more general occurrence of energetic abilities between the age of 11 and 13 and a tendency to specification of co-ordination abilities yet before the observation period. In both the sportsmen's and less physically active boys' groups the number of separated factors did not increase as well as the set of variables taken into account. It can be concluded, then, that the applied way of sports selection as well as the process of their adaptation to specific training ballast might have been the causative factor of the structure efficiency specification, among children from sports schools. In this connection, they cannot deny the thesis that a talented sports champion can be recognized already as a child. Still, the ways of such a selection seem controversial. An effort should certainly be taken to solve the mentioned problem. It seems that the presented results of the individual research may be treated as a contribution to the discussion about the choice of an economical and efficient methodical way during a selection and training of future football champions.

\section{CONCLUSIONS}

1. It was noticed that the motor potential of the training boys was different from that of the comparative group of the same age. The statistic analysis allowed to reveal a large number of factors as the result of the reduction of multicharacteristic initial set.
2. The results of the studies give evidence that the applied model of children's selection to playing football in sports classes was effective. Trainers' expert opinion during matches, tactic skills and talent of football candidates for sports training were taken into account in the model.

3. In a progress of a professional sports training the process of adaptation of the motor potential of the sports class pupils to specific demands of the trained sports was noticed. This phenomenon did not refer to the separated characteristics in factor I - 'body fat'. It may suggest its importance for football efficiency and training effects of children from sports schools.

4. Among non-training boys between 11 and 13 years old a more general occurrence of energetic abilities and tendency to specification of coordination abilities can be noticed yet before the observation period.

5. In both the sportsmen's and less physically active boys' groups the number of separated factors did not increase as well as the set of variables taken into account. It can be concluded then, that the applied way of sports selection as well as the process of their adaptation to a specific training ballast might have been the causative factor of the structure efficiency specification among children from sports schools. In this connection, they cannot deny the thesis that a talented sports master can be recognized already as a child. Still, the ways of such a selection seem controversial.

\section{REFERENCES}

Costil, D. L. (1976). Naukowe podstawy treningu długodystansowca. Sport Wyczynowy, 8, 44-76.

Czyż, T. (1971). Zastosowanie analizy czynnikowej do badania struktury ekonomicznej regionalnej Polski. Prace Geograficzne, 92, 26-34.

Eurofit. European Test of Physical Fitness. (1993). Strasbourg: Council of Europe Committee for the Development of Sport.

Filippowič, W. I.,Turewskij, I. M.(1977). O principach sportiwnoj orientacji dietiej i podrostkow w swjazi wozrostnoj izmiencziwostju struktury dwigatielnych sposobnostiej. Teoria i Praktika Fiziczeskoj Kultury, 4, 39-43. Greń, J. (1976). Statystyka matematyczna. Modele i zadania. Warszawa: PWN.

Januszewski, J., Mleczko, E. (2003). Analiza czynnikowa w świetle badań porównawczych. Antropomotoryka, 25, 25-38.

Januszewski, J. (1981). Pomiar zdolności wysiłkowej dziewcząt i chłopców w wieku szkolnym - zmodyfikowanym testem Margarii. Wychowanie Fizyczne i Sport, 1, 3-12.

Marek, T., Noworol, Cz. (1983). Wprowadzenie do analizy skupień. Kraków: Uniwersytet Jagielloński.

Raczek, J. (1981). Szkolenie młodzieży w systemie sportu wyczynowego. Katowice: AWF.

Szopa, J., Mleczko, E., Żak, S. (1996). Podstawy antropomotoryki. Warszawa-Kraków: PWN.

Ważny, Z. (1981). Wspótczesny system szkolenia sportowego. Warszawa: Sport i Turystyka. 


\title{
JAUNŲJŲ FUTBOLININKŲ FIZINIO PARENGTUMO STRUKTŪRA PER TREJŲ METŲ TRENIRUOTÉS CIKLĄ
}

\author{
Edward Mleczko ${ }^{1,3}$, Elżbieta Cieśla ${ }^{3}$, Grażyna Nowak-Starz ${ }^{3}$ Jan Jaščaninas ${ }^{2,4}$ \\ Krokuvos kūno kultūros akademija ${ }^{1}$, Krokuva, Lenkija, Lietuvos kūno kultūros akademija ${ }^{2}$, Kaunas, \\ Lietuva, Saint Cross Universitetas ${ }^{3}$, Kielce, Lenkija, Opolès Politechnika ${ }^{4}$, Opolè, Lenkija
}

\section{SANTRAUKA}

Longitudinių tyrimų, atliktu Tarnovo (Lenkijos) sporto mokyklos futbolininkų klasėse, metu faktoriu analizès būdu siekta nustatyti, ar pastebimi motorinio talento rodiklių pokyčiai taikant techninio ir taktinio ugdymo programą? Panašūs tyrimai buvo atliekami ir to paties amžiaus nesportuojančių vaikų klasėse. Tirti somatiniai pokyčiai, antropometrinis indeksas, $\mathrm{VO}_{2 \max } / \mathrm{kg}$, motoriniu gebèjimų rodikliai. Buvo tiriama 30 futbolo klasių berniukų ir 90 nesportuojančių to paties amžiaus moksleivių. Tyrimai tęsèsi trejus metus ir buvo atliekami kas 6 mėnesius rudenị ir pavasarị.

Faktorių analizės rezultatai parodė, kad trejų metų tyrimo laikotarpiu jaunujų fubolininkų ir nesportuojančiu bendraamžių grupėse aptikti nedideli motorinio parengtumo struktūros kiekybiniai skirtumai. Sportininku̧, kaip ir mažesnio judejjimo aktyvumo vaiku, tam tikri judrumo rodikliai buvo vienodi. Taigi galima teigti, kad futbolo sporto mokykloje taikomas atrankos modelis ir vèliau pasireiškianti motorinès funkcijos adaptacija prie treniruočių krūvių galèjo formuoti specialaus fizinio parengtumo struktūrą. Tyrimo duomenys patvirtina hipotezę, kad futbolininko motorini talentą galima pastebėti jau vaikystėje, nors iki tol nuomonès šiuo klausimu skyrėsi. Taigi sportinès atrankos eiga, vykdoma pastarojo teiginio pagrindu, gali kelti abejonių.

Raktažodžiai: jaunųjų futbolininkų fizinio parengtumo struktūra, motorinis talentas, longitudiniai tyrimai, faktoriu analizè.

Gauta 2005 m. spalio 24 d.

Received on October 24, 2005

Priimta 2005 m. gruodžio 28 d.

Accepted on December 28, 2005

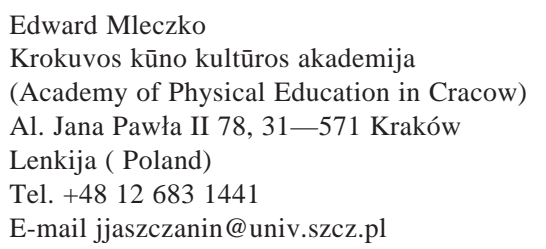

